\title{
Influence of Metals In Soil on The Comparative Phyto chemical Characterization and Antioxidant Study of Indian Golden Shower (Cassia Fistula)
}

\author{
Kuntal Das ${ }^{*}$, Raman Dang1', Guruprasad Sutar V², John Wilking Einstein ${ }^{3}$, Ranjit Kumar Paul', \\ Tanmoy Karak ${ }^{5}$ \\ ${ }^{1}$ Krupanidhi College of Pharmacy, 12/1, Chikka Bellandur, Carmelaram Post, Varthur Hobli, Bangalore - 35, Karnataka, INDIA. \\ ${ }^{2}$ Arvind Gavali College of Pharmacy, Jaitapur Post, Chinchner Vandan, Dist. Satara, Maharashtra - 04, INDIA. \\ ${ }^{3}$ University of Malaya, Kuala Lumpur, Malaysia \\ ${ }^{4}$ Indian Agricultural Statistics Research Institute, New Delhi 110012, INDIA. \\ ${ }^{5}$ Upper Assam Advisory Centre, Tea Research Association, Dikom 786101, Assam, INDIA.
}

\begin{abstract}
Objective: This paper highlighted the effect of selected soil containing metals, viz. Cd, $\mathrm{Cr}, \mathrm{Cu}, \mathrm{Fe}, \mathrm{Ni}, \mathrm{Pb}$ and $\mathrm{Zn}$ on the biochemical compositions and antioxidant activity in leaf of 20 years old two Cassia fistula L. (CF) cultivars. The leaf samples were collected from CF grown on road sides from the states of Maharashtra and Karnataka in India. Methods: Antioxidant activity and total phenol contents from methanolic and aqueous leaf extract were evaluated by assays like oxygen radical absorbance capacities (ORAC), 2, 2'-Azino-bis (3-ethylbenzothiozoline-6-sulphonic acid) diammonium salt (ABTS) and folin- ciocalteu reagent methods respectively. Maximum dose dependent antioxidant activity was observed in methanol leaf extract of both the cultivars, but marginal variation observed in antioxidant activity. Results: The result revealed that total phenolic content was maximum in the methanolic leaf extract $111.40 \pm 0.37 \mathrm{mg} \mathrm{g}^{-1}$ of gallic acid equivalent). A positive correlation between antioxidant activity and total phenol compounds was noticed from both the samples. Furthermore a significant correlation was observed between element contents and antioxidant activities. Conclusion: This was may be due to elements like $\mathrm{Fe}, \mathrm{Cu}$, and $\mathrm{Zn}$ for accumulation of secondary constituents in the methanolic leaf extract that are major contributors to the antioxidant potential of $\mathrm{CF}$. There were no other heavy metals $(\mathrm{Ni}, \mathrm{Cd}, \mathrm{Pb}$ and $\mathrm{Cr}$ ) reported in both the samples.
\end{abstract}

Key words: Antioxidant, CF leaf, Metal risk, Soil, Total phenols.

\section{INTRODUCTION}

Heavy metals (HMs) pollution in soils is growing concern due to the combined effects of industrialization as well as agricultural practices like long-term use of phosphate fertilizers, sewage sludge application, use of road side pond sediments, dust from smelters, industrial waste and bad watering practices. ${ }^{1-2}$ Some metals are known as micronutrients for plants, viz. $\mathrm{Cu}, \mathrm{Mn}$ and $\mathrm{Zn}$ however, those may act as heavy metals if their concentration is soils exceed their permit limits. ${ }^{3} \mathrm{On}$ the other hand $\mathrm{Cd}, \mathrm{Cr}$ and $\mathrm{Pb}$ are well known HMs in soils for their long persistence and adverse effect on plant's health. Several studies unequivocally confirmed that heavy metals in plants from contaminated soils and nutrient solutions results in impaired metabolism and retarded growth through the generation of free radicals and reactive oxygen species. ${ }^{4-6}$ Furthermore, the most deleterious effects induced by HMs exposure cause bio-membrane deterioration in plants due to lipid peroxidation. ${ }^{2}$
Submission Date : 04-03-2016 Revision Date : :12-05-2016 Accepted Date : :05-07-2016

DOI: 10.5530/ijper.50.3.37 Correspondence: Kuntal Das,

Krupanidhi College of Pharmacy, 12/1, Chikka Bellandur, Carmelaram Post, Varthur Hobli, Bangalore, Karnataka, INDIA. Tel.:+ 919632542846; Fax: +91-80-25535751 E-mail addresses: drkkdsd@ gmail.com

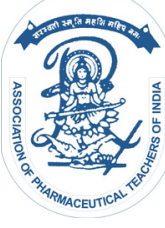

www.ijper.org 
C. fistula L. is a semi-wild, a lesser-known legume, ethno medicinal perennial plant grown in different parts in the world. This plant can be found in various countries in Asia, South Africa, Mexico, China, India, West Indies, East Africa and Brazil. ${ }^{7-8}$ This plant is also known as "Golden Shower" for its beautiful showy yellow flowers which make this plant as an ornamental plant. ${ }^{7}$ Different parts of this plant are widely used to treat ringworm as well as several fungal skin infections, nasal infection, anti-fungal drug, to treat inflammation, anti inflammatory, abdominal pain, leprosy, antipyretic, abortifacient, demulcent, purgative, refrigerant, good for chest complaints, eye ailments, flu, heart and liver ailments and rheumatism. ${ }^{9}$ It is useful in treating haematemesis, pruritus, eucoderma and diabetes. ${ }^{10}$ C. fistula exhibited significant antibacterial/ antifungal activities and showed properties that support folkloric use in the treatment of some diseases as broadspectrum antimicrobial agents. ${ }^{8}$ These activities are due to the presence of many secondary metabolites namely anthraquinones, flavonoids, flavan-3-ol derivatives, phenolic compounds and steroidal compound. ${ }^{11}$

Very recent study reported by Karak et al. (2013). ${ }^{12}$ concluded that HMs contaminated roadside pond sediment can increase the level of antioxidants (cysteine and ascorbic acid) in roots, shoots and leaves of Brassica juncea which makes the plant is well adapted to tolerate and accumulate high quantities of HMs. Hence the role of heavy metals on antioxidant activity in plant is an important focus which can't be overlooked. On the other hand, the use of total HMs concentration as a criterion to assess the potential effects of soil contamination implies that all forms of a given element have an equal impact on the environment; such an assumption is clearly untenable. ${ }^{13,14}$ Therefore, fractionation of soil HMs is an important tool of chemical characterization and can provide useful information on its bioavailability. ${ }^{15}$ Even though medicinal plants have several beneficial effects, a recent systematic review by Street (2012). ${ }^{6}$ concluded that various medicinal plants can accumulate HMs. For example, medicinal plants like Senecio coronatus (Thunb.) Harv. (Asteraceae), Datura metal L. (Solanaceae), Datura innoxia, Helichrysum candolleanum $\mathrm{H}$. Buek (Asteraceae), Blepharis diversispina (Nees) C. B. Clarke (Acanthaceae) and Rauwolfa vomitoria (Apocynaceae) are accumulator of $\mathrm{Ni}, \mathrm{Co}$ and $\mathrm{Ni}, \mathrm{Zn}, \mathrm{Cu}, \mathrm{Ni}$ and $\mathrm{Fe}$ respectively ${ }^{16-19}$ Therefore, consumption of HMs containing medicinal plants or plant products may invite countless health implications ${ }^{6}$ even though interest in medicinal plants reflects the recognition of the cogency of many traditional privileges as they are excellent sources of functional ingredients. ${ }^{8}$ For example, low-level chronic exposure to $\mathrm{Cd}$ may have adverse effects on gastrointestinal, hematological, musculoskeletal, renal, neurological and reproductive systems of the target population..$^{20}$ An acute dose of cadmium (10-30 $\left.\mathrm{mg} \mathrm{kg}^{-1} \mathrm{~d}^{-1}\right)$ may cause severe gastrointestinal irritation, vomiting, diarrhea, and excessive salivation, and a dose of $25 \mathrm{mg} \mathrm{kg}^{-1}$ body weight ${ }^{-1}$ can cause death. Lead ingestion above the safe permissible limit may lead to changes in blood enzyme activity, kidney damage, changes in muscle function, lung and gastric cancer or decreased ability to learn. ${ }^{21}$ Hyper intake of nickel may lead to hypoglycemia, asthma, nausea, and headache. The permissible safe limit of $\mathrm{Ni}$ is $3.0-7.0 \mathrm{mg}$ day ${ }^{-1}$ in humans. ${ }^{20}$ Excess of zinc in the diet may cause vomiting, renal damage, sideroblastic anaemia and cramps. ${ }^{22}$

When a plenty of literatures are available on HMs accumulation in medicinal plants, HMs contents in the leaf of CF are scanty. Moreover, to the best of our knowledge, the effect of HMs on biochemical properties in the leaf of CF has not been reported so far. HMs in growing plants also varied with various factors, especially geographical locations and soil factors. In view of the above facts, the present studies were aimed to evaluate the ability of previously reported chemical extracts to measure the bioavailable fraction of selected HMs, viz. $\mathrm{Cu}, \mathrm{Mn}, \mathrm{Zn}, \mathrm{Cd}, \mathrm{Cr}$ and $\mathrm{Pb}$ in soils collected from two CF growing regions in South India. Biochemical properties (total phenolic and antioxidant) of leaf extracts have also been investigated to understand the effects of HMs on it.

\section{Materials and Methods}

\section{Reagents}

All the chemicals used in the present experiment were of high grade quality. Sodium di-hydrogen phosphate and di-sodium hydrogen orthophosphate di hydrate were purchased from Hi Media Laboratories (Mumbai, India,). Ammonium persulphate was procured from Rankem, Avantor Performance Materials India Limited (Thane, Mumbai, India]. 2,2'-azino-bis(3-ethylbenzothiozoline-6-sulphonic acid) diammonium salt (ABTS) and ( \pm )-6-hydroxy-2,5,7,8-tetramethylchromane-2-carboxylic acid (Trolox); 2,2'-azobis(2-methyl propionamidine) dihydrochloride (AAPH); fluorescein sodium salt; 3,4,5-Trihydroxy benzoic acid (gallic acid) and phosphate buffered saline ( $\mathrm{pH}$ 7.4) were purchased from Sigma-Aldrich Co. LLC (Bengaluru, India). CertiPUR ${ }^{\circledR}$ AAS standards (Merck Millipore, Germany) were used for metal analysis.

\subsection{Study area}

Kolhapur of Chandgad District in the state of Maharashtra (Latitude 16 $6^{\prime} 0^{\prime \prime} \mathrm{N}$ and Longitude 
$78^{\circ} 18^{\prime} 0^{\prime \prime} \mathrm{E}$ ) and from Bangalore in the state of Karnataka (Latitude $12^{\circ} 58^{\prime} 38 \mathrm{~N}$ and Longitude $77^{\circ} 35^{\prime} 14 \mathrm{E}$ ) in India were selected for the present study (Figure 1). Kolhapur's climate is a blend of coastal and inland elements common to Maharashtra and the temperature have a relatively narrow range between $10^{\circ} \mathrm{C}$ and $35^{\circ} \mathrm{C}$. The city receives abundant rainfall in August due to its proximity to the Western Ghats and average precipitation for this month is around $181.6 \mathrm{~mm}$. Bangalore (officially known as Bengaluru) has a tropical savanna climate with distinct wet and dry seasons. Like Kolhapur, temperature of Bangalore has a relatively narrow range between $15.4^{\circ} \mathrm{C}$ and $36^{\circ} \mathrm{C}$. Bangalore receives average rainfall $142.5 \mathrm{~mm}$ for the month of August.

\section{Plant leaf sampling and pretreatment}

Road side naturally growing CF plants (plant age is around 20 years) were selected from Kolhapur of Chandgad District in the state of Maharashtra (sample ID: $\mathrm{CF}-\mathrm{MH}$ ) and from Bangalore in the state of Karnataka (sample ID: CF-KAR) during the month of August, 2012. Only leaf samples were collected from the plants for the present study. It was done as tree leaves are commonly used for bio monitoring and it is a reliable indicator of environmental pollution to monitor a wide range of heavy metals in soils, air and water as suggested by Tarricone et al. (2015). ${ }^{23}$ Leaves samples were carefully rinsed with tap water and then with deionized water. The leaves collected from two locations were air dried in shade at room temperature and powdered with a grinding machine. The plant samples were identified and authenticated by Dr. N. Shiddamallaya, Botanist, National Ayurveda Dietetics Research Institute, Bangalore (Karnataka) and the voucher specimens have been preserved at the herbarium of Pharmacognosy (No: Pharm/CF-MH/120/GS-2012 and Pharm/CFKAR/121/GS-2012), Arvind Gavali College of Pharmacy (Satara, Maharashtra) for future reference.

\section{Soil sampling and pretreatment}

Representative surface $(0-15 \mathrm{~cm})$ soil samples were collected using stainless steel soil augers from the location where plant samplings were made. Sample IDs of collecting soils have been given as $\mathrm{MH}$ and KAR for Maharashtra and Karnataka respectively. Soil samples were pretreated for analysis and preserved according to the protocol described by Rubio and Ure (1993). ${ }^{24}$

\section{Plant sample analysis}

\section{Crude extract preparation}

Both methanol and aqueous extracts from leaf were carried out. $1 \mathrm{~L}$ of $80 \%$ methanol was used for methanolic extraction when exactly $300 \mathrm{~g}$ of dried leaf had been taken in a $2 \mathrm{~L}$ conical flask and then the flask was heated for $6 \mathrm{hrs}$ at $60^{\circ} \mathrm{C}$ in heating mantle. The extract was then filtered using a Millipore filter with $0.45 \mu \mathrm{m}$ nylon membrane under vacuum at $23^{\circ} \mathrm{C}$. Thereafter the filtrate was taken in a rotary vacuum evaporator and methanol was removed to get crude extract. For water extract, $300 \mathrm{~g}$ dried leaf sample was added to $1 \mathrm{~L}$ distilled water in a $2 \mathrm{~L}$ conical flask and heated for 3 hours at $80^{\circ} \mathrm{C}$ in a water bath. After extraction, the slurry was filtered through filter paper (Whatman No. 1) and crude extracted was made by using a rotary vacuum evaporator. All the extracts were kept in glass bottles and stored at $4^{\circ} \mathrm{C}$ with proper labeled until until the time of phytochemical studies and bioactivity were performed. Yields $(\mathrm{w} / \mathrm{w})$ of the extracts were calculated and tabulated in the result section.

\section{Total metal analysis of leaf extracts and quality control}

Accurately $0.5 \mathrm{~g}$ solid extract of sample separately weighted from each individual extract into a $100 \mathrm{~mL}$, pyrex digestion tube and wetted with a few drops of deionized water. The sample was digested for $20 \mathrm{~min}$ in a microwave digester at $80^{\circ} \mathrm{C}$ with three acids dissolution method ( $2 \mathrm{~mL} \mathrm{HCl}, 1 \mathrm{~mL} \mathrm{HNO}_{3}$ and $1 \mathrm{~mL} \mathrm{HF}$ ). Subsequently the digested samples were diluted with deionized water (18.2 $\mathrm{M} \Omega \mathrm{cm}^{-1}$ resistivity) to a total volume $50 \mathrm{~mL}$. Final solutions were analysed for $\mathrm{Cd}, \mathrm{Cr}$, $\mathrm{Cu}, \mathrm{Fe}, \mathrm{Ni}, \mathrm{Pb}$ and $\mathrm{Zn}$ using atomic absorption spectrophotometer (AAS; Perkin Elmer model: A Analyst 100; Australia). Blank samples were also prepared for corrections. All the samples were checked by carrying out triplicate analyses for the reproducibility of the method used. The mean value of concentrations for each element has been reported along with standard deviation.

The accuracy and precision of the analyses for metals were checked against SRM-2709 (San Joaquin soil from the National Institute of Standards and Technology, Gaithersburg, MD), SRM-1645 (river sediment from the National Bureau of Standards, Washington, D.C.) and SRM-1515 (apple leaves, National Institute of Standards and Technology, Japan). Analyses of these SRMs showed that all the certified and reference elements were within the expected values (95 to $110 \%$ recovery). Therefore, the results of the SRMs showed a good agreement with the certified and reference values for all the analyzed elements. 


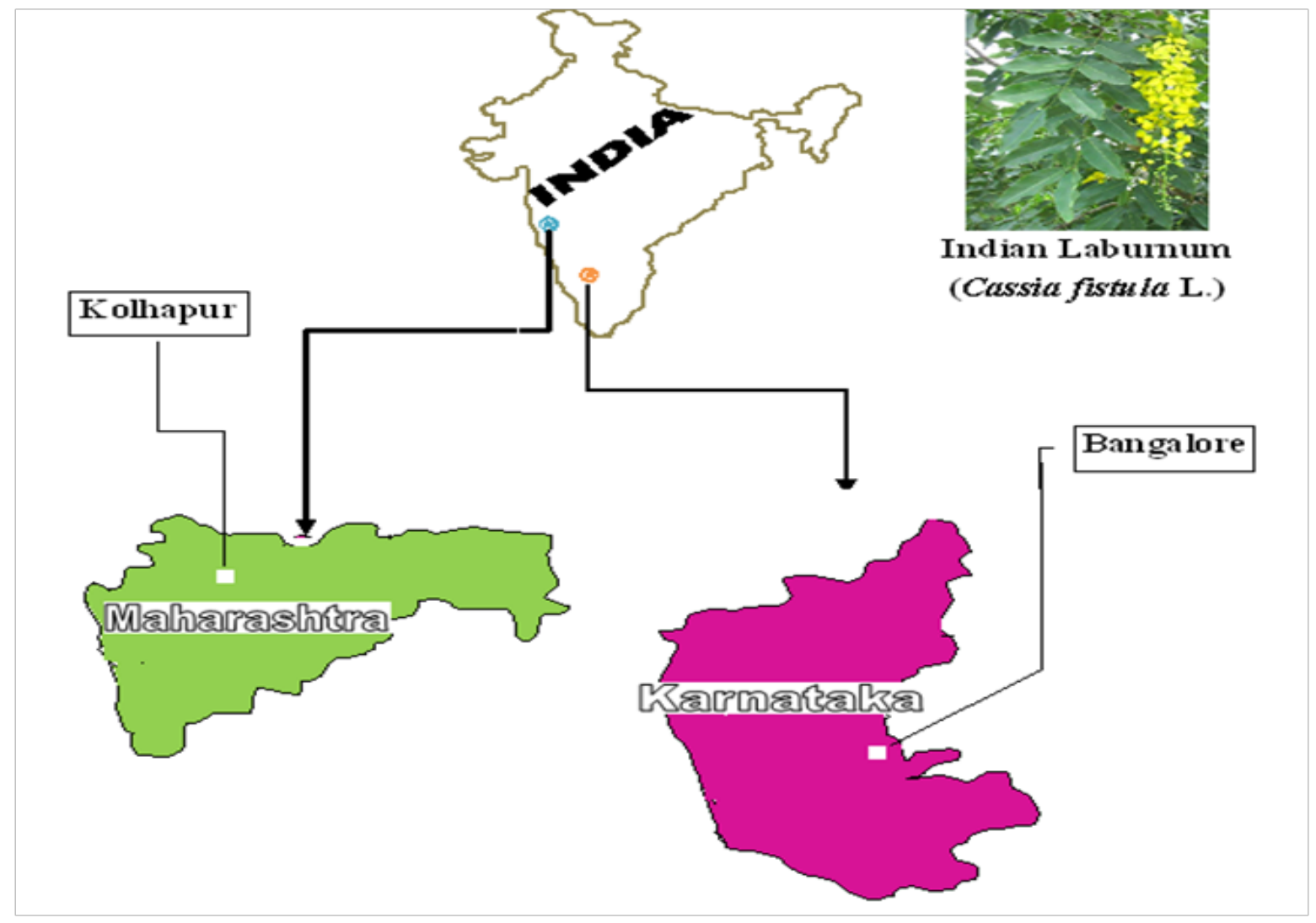

Figure 1: The map showing the locations of $C$. fistula L. growing regions from where soil samples and leaf samples were collected in the states of Maharashtra and Karnataka, India.

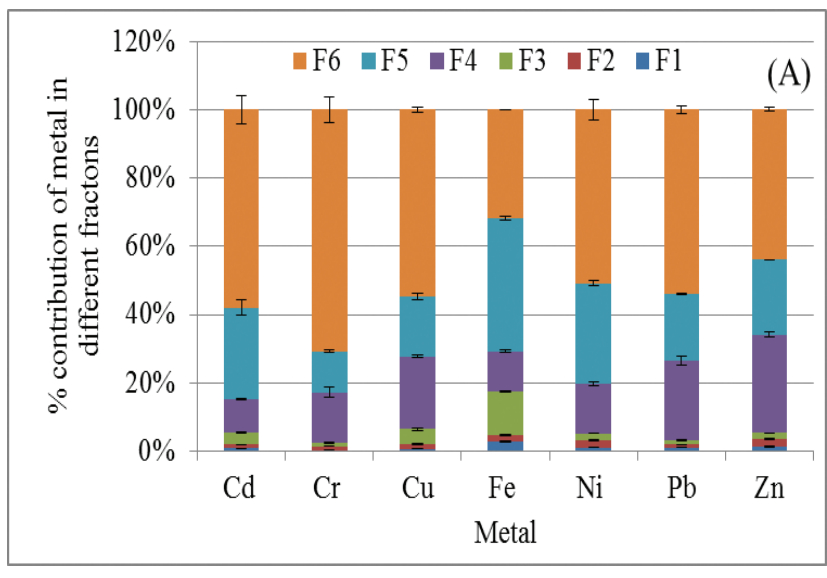

Total heavy metals in $\mathrm{mg} \mathrm{kg}^{-1}$ (sample ID: MH)

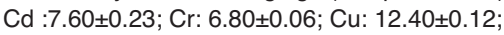
Fe: $88.90 \pm 2.66$; Ni: $9.40 \pm 0.58 ; \mathrm{Pb}: 10.48 \pm 0.53$ and $\mathrm{Zn}: 54.65 \pm 2.23$

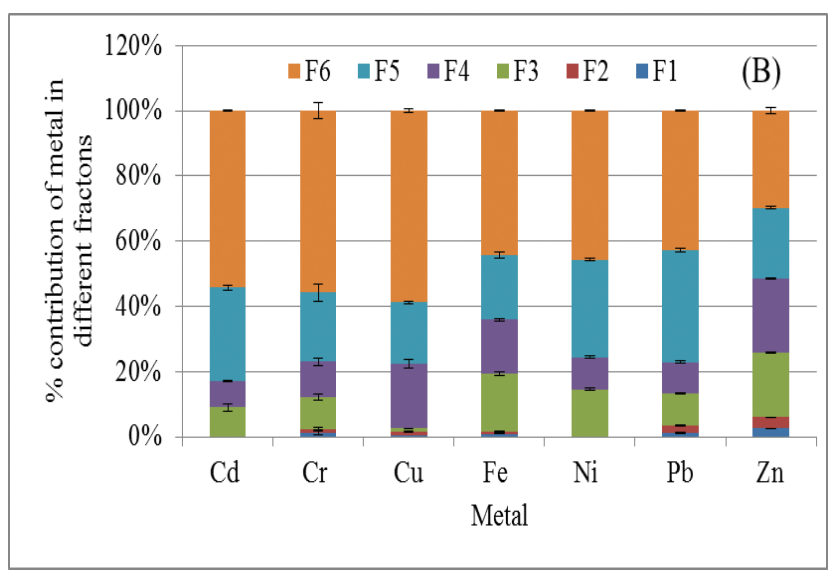

Total heavy metals in $\mathrm{mg} \mathrm{kg}^{-1}$ (sample ID: KAR)

Cd: $7.20 \pm 0.06 ; \mathrm{Cr}: 6.40 \pm 0.16 ; \mathrm{Cu}: 13.30 \pm 0.12 ; \mathrm{Fe}: 86.70 \pm 0.62 ; \mathrm{Ni}: 8.80 \pm 0.47$; $\mathrm{Pb}: 11.55 \pm 0.47$ and $\mathrm{Zn}: 58.20 \pm 0.24$

Figure 2: Distribution pattern of heavy metals in various operationally defined geochemical fractions in soils including their total concentrations: (A) Chandgad District, Kolhapur, Maharashtra series (sample ID:MH) and (B) Bangalore, Karnataka series (sample ID:KAR) [F1:water-soluble, F2: exchangeable; F3: bound to carbonates; F4: bound to Fe-Mn oxides; F5: organically bound and F6: residual fractions; vertical line indicates standard error bar]. 


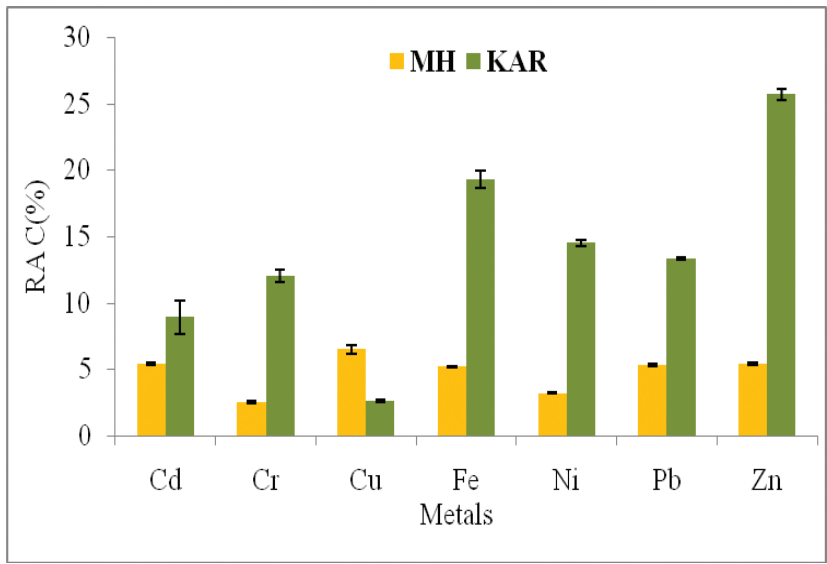

Figure 3: Risk assessment code (RAC) of heavy metals in the experimental soils.

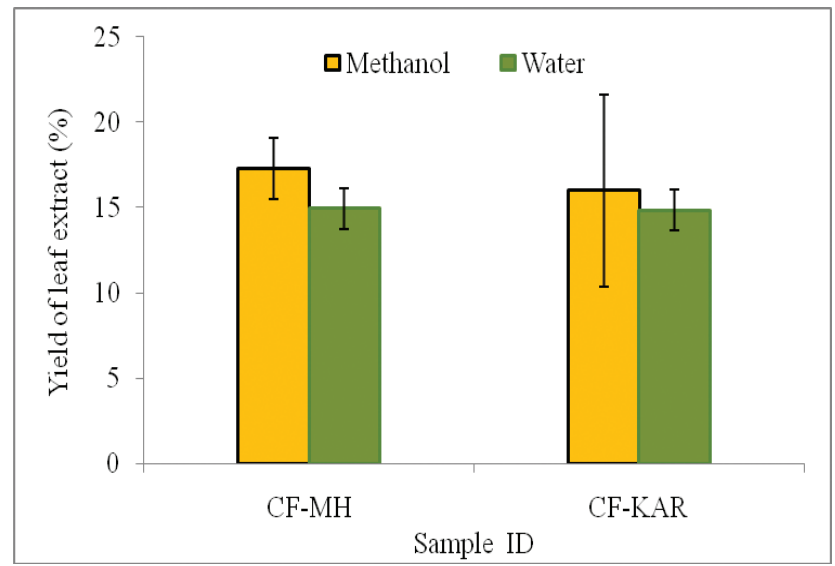

Figure 4: Yield of extracts by methyl alcohol and water as solvent from the leaf of $C$. fistula $\mathrm{L}$. collected from two different states of India.

\begin{tabular}{l}
\begin{tabular}{|c|c|c|c|c|}
\hline $\begin{array}{c}\text { Heavy } \\
\text { metals }\end{array}$ & \multicolumn{2}{|c|}{ Sample ID } & \multicolumn{2}{c|}{$\begin{array}{c}\text { Category of soil with } \\
\text { respect to RAC } \\
\text { (Singh et al., 2005) }\end{array}$} \\
\hline & MH & KAR & MH & KAR \\
\hline $\mathrm{Cd}$ & $5.4 \pm 0.07$ & $8.9 \pm 1.22$ & $\mathbf{2}$ & $\mathbf{2}$ \\
\hline $\mathrm{Cr}$ & $2.5 \pm 0.08$ & $12.0 \pm 0.45$ & $\mathbf{2}$ & $\mathbf{3}$ \\
\hline $\mathrm{Cu}$ & $6.5 \pm 0.32$ & $2.6 \pm 0.09$ & $\mathbf{2}$ & $\mathbf{2}$ \\
\hline $\mathrm{Fe}$ & $5.2 \pm 0.06$ & $19.3 \pm 0.67$ & $\mathbf{2}$ & $\mathbf{3}$ \\
\hline $\mathrm{Ni}$ & $3.2 \pm 0.07$ & $14.5 \pm 0.23$ & $\mathbf{2}$ & $\mathbf{3}$ \\
\hline $\mathrm{Pb}$ & $5.3 \pm 0.12$ & $13.3 \pm 0.09$ & $\mathbf{2}$ & $\mathbf{3}$ \\
\hline $\mathrm{Zn}$ & $5.4 \pm 0.07$ & $25.7 \pm 0.40$ & $\mathbf{2}$ & $\mathbf{3}$ \\
\hline
\end{tabular} \\
$\begin{array}{l}{ }^{*} \mathrm{RAC}:<1 \text { (category } \mathbf{1} \text {, no risk); } 1-10 \text { (category } \\
\text { medium risk); }>30-50 \text { (category } \mathbf{4}, \text { high risk) and }>50 \text { (category }\end{array}$ \\
\hline
\end{tabular}

\section{Preliminary phytochemical screening}

\section{Determination of the total phenolics}

The total phenolic content (TPC) of each leaf sample was estimated using the modified Folin-Ciocalteu colorimetric method according to Pourmorad et al. (2006). ${ }^{25}$ Appropriately $0.2 \mathrm{~mL}$ aliquots of leaf extracts were taken in a test tube and mixed with $0.5 \mathrm{~mL}$ of FolinCiocalteu reagent for $4 \mathrm{~min}$ at room temperature. Thereafter the mixture was neutralized with $20 \%$ $1.5 \mathrm{~mL}$ of the sodium carbonate solution and allowed to stand for $2 \mathrm{~h}$ in the dark at room temperature. to develop blue color. Absorbance of resulting blue colour solution was measured at $760 \mathrm{~nm}$ using the UV spectrophotometer (Varian Cary 50 Biospectrophotometer, Australia). The phenolic content in the sample was calculated using standard curve with Gallic acid. The results were expressed as $\mathrm{mg} \mathrm{g}^{-1}$ of
Gallic acid equivalent (GAE) per g dry mass (DM) sample.

\section{Antioxidant evaluation}

\section{Oxygen radical absorbance capacity (ORAC) assays}

ORAC assays were performed following the protocol described by Deng et al (2014). ${ }^{26}$ with modification. The reaction was conducted at $37^{\circ} \mathrm{C}$ for 10 mins at $\mathrm{pH}$ 7.0.in an incubator. In brief, the final reaction mixture $(140 \mu \mathrm{L})$ consisted of $20 \mu \mathrm{L}$ of test solution with TROLOX of various concentrations $\left(0-100 \mu \mathrm{mol} \mathrm{L}^{-1}\right), 75 \mathrm{mM}$ sodium phosphate buffer at $\mathrm{pH} 7.4$ and $120 \mu \mathrm{L}$ of sodium fluorescein $(117 \mathrm{nM})$. After that, the mixture was heated in the hot plate at $37^{\circ} \mathrm{C}$ for $20 \mathrm{~min}$. After that the AAPH solution was added to initiate the antioxidant radical reactions. The fluorescence of the mixture was recorded every 2 min over $2 \mathrm{~h}$ at $37^{\circ} \mathrm{C}$. Excitation and emission wavelengths were 480 and $520 \mathrm{~nm}$, respectively for the 
fluorescence measurements. The results of the ORAC test are calculated with a straight standard line obtained with the Trolox standards and are expressed as mM Trolox equivalent (TE) per gram freeze-dried weight.

\subsubsection{ABTS assay}

$12.5 \mathrm{mg}$ of solid methanol as well as water extracts were separately dissolved in $2.5 \mathrm{~mL}$ of methanol and $2.5 \mathrm{~mL}$ of water respectively. The volume was made up to $5 \mathrm{~mL}$ in $0.01 \mathrm{M}$ phosphate buffered saline ( $\mathrm{pH}$ 7.4). The stock was diluted to the required concentration and used in the assay. The assay is performed as per Auddy et al (2003). ${ }^{27}$ ABTS radical cations are produced by reacting ABTS/APS and incubating the mixture at room temperature in the dark for 16 hours. In brief, the total reaction volume contained $20 \mu \mathrm{L}$ of $10 \mathrm{mM}$ PBS, $\mathrm{pH} 7.4$, vehicle buffer, positive control, test solutions of various concentrations and $230 \mu \mathrm{L}$ of ABTS radical solution $(0.238 \mathrm{mM})$. The mixture was thoroughly mixed and immediately read at $734 \mathrm{~nm}$ using a microplate reader (Molecular devices Versa max micro plate reader). A control reaction was carried out without the test sample.

\section{Soil characterization}

The $\mathrm{pH}$ was measured with a glass electrode using a 1:1 sample/ water ratio and electrical conductivity (EC) was measured with a meter and probe as using a 1:5 sample/water ratio. ${ }^{28}$ The soil redox potential (Eh) was measured using a standard Pt electrode (HORIBA redox potential meter, Japan). Mechanical analysis was carried out by International pipette method. ${ }^{29}$ to determine the percentages of sand, silt and clay from soils. Determinations of cation exchange capacity (CEC) were made in $\mathrm{BaCl}_{2}$ by the Gilman method. ${ }^{30}$ and total organic $\mathrm{C}$ was determined by the Walkley and Black wet dichromate oxidation method. ${ }^{31}$ Phosphate $\left(\mathrm{PO}_{4}^{3-}\right)$ was determined colorimetrically (Varian Cary 50 Bio spectrophotometer, Australia) according to the method described by Peachey et al. (1973). ${ }^{32}$ Total heavy metals in soil, compost and plant parts were extracted according to the three acids dissolution method, described by Cappuyns et al. (2002). ${ }^{33}$ Assessment of potentially phyto-available metals $(\mathrm{Cd}, \mathrm{Cr}, \mathrm{Cu}, \mathrm{Fe}, \mathrm{Ni}, \mathrm{Pb}$, and $\mathrm{Zn}$ ) in soils was conducted using the DTPA/TEA method, developed by Lindsay and Norvell (1978). ${ }^{34}$ Six step sequential extraction (F1: water-soluble; F2: exchangeable, F3: bound to carbonates, F4: bound to Fe and Mn, F5: organically bound and F6: residual fractions) of soil was conducted by using the protocol described by Tessier et al. (1979). ${ }^{35} 2 \mathrm{~g}$ of air-dried and sieved sample was used for this procedure. All the extraction steps were performed in $50 \mathrm{ml}$ polypropylene centrifuge tubes with screw caps. The experimental details of the technical procedures for chemical fractionation may be found elsewhere. ${ }^{36}$ Extracted heavy metal concentrations were determined using an atomic absorption spectrophotometer (AAS; Perkin Elmer model: AAnalyst 100; Australia). From the fractionation study, risk assessment code (RAC) of metals in soil was performed following the procedure described by Singh et al. (2005), ${ }^{37}$ as:

$$
\operatorname{RAC}(\%)=\left(\sum_{n=1}^{n=3} F_{n} / \sum_{n=1}^{n=6} F_{n}\right)
$$

where "Fn" is the concentration of metal in " $\mathrm{n}$ "th" fraction.

\section{Statistical analysis}

The two samples t-test was used for testing the significance differences in all the elements between two places. Before conducting t-test, equality of variances was tested by using F-test. A brief discussion of the above statistical test procedures is given below.

\section{Equality of variance test}

For testing the equality of variances of two populations, the F-test statistic as given by $\mathrm{F}=\mathrm{s}_{1}{ }^{2} / \mathrm{s}_{2}{ }^{2}$, is used where $\mathrm{s}_{1}{ }^{2}$ and $\mathrm{s}_{2}{ }^{2}$ are the sample variance of population 1 and population 2 respectively. It is assumed that $\mathrm{s}_{1}{ }^{2}$ is the largest among two variances. The $\mathrm{F}$ statistic follows an $\mathrm{F}$ distribution with $\left(\mathrm{n}_{1}-1, \mathrm{n}_{2}-1\right)$ degrees of freedom.

\section{Hypothesis Testing with Two Independent Samples $\mathbf{t}$}

The assumptions for two sample t-test are: 1 . the two samples are independent. 2 . The two samples are randomly selected from normally distributed populations. 3. The population variances are equal. Assume that $\left(\mu_{1}, \sigma_{1}{ }^{2}\right)$ and $\left(\mu_{2}, \sigma_{2}{ }^{2}\right)$ are the population mean and variances of two populations respectively. $\left(\bar{x}_{1}, s_{1}{ }^{2}\right)$ and $\left(\bar{x}_{2}, s_{2}{ }^{2}\right)$ are the sample mean and sample variance of two sample respectively. $\mathrm{n}_{1}, \mathrm{n}_{2}$ is the sample size of two samples respectively.

Assuming Equal Population Variances/Standard Deviations (pooled t-Test) i.e. $\left(\sigma_{1}{ }^{2}=\sigma_{2}{ }^{2}=\sigma^{2}\right)$

The test statistic is given as:

$$
t=\frac{\left(\bar{x}_{1}-\bar{x}_{2}\right)-\left(\mu_{1}-\mu_{2}\right)}{s \sqrt{\frac{1}{n_{1}}+\frac{1}{n_{2}}}} \sim t
$$

distribution with $d f=\left(n_{1}+n_{2}-2\right)$

where, $s=\sqrt{\frac{\left(n_{1}-1\right) s_{1}^{2}+\left(n_{2}-1\right) s_{2}^{2}}{n_{1}+n_{2}-2}}$ 
Table 1: Geochemical properties of the collected soils (values represent mean of three replications \pm SE, same letter(s) in a particular row represent non-significant difference between the samples)

\begin{tabular}{|c|c|c|}
\hline \multirow{4}{*}{ Parameters } & \multicolumn{2}{|c|}{ Location } \\
\hline & $\begin{array}{c}\text { Chandgad District, } \\
\text { Maharashtra }\end{array}$ & Bangalore, Karnataka \\
\hline & \multicolumn{2}{|c|}{ Sample ID } \\
\hline & MH & KAR \\
\hline $\mathrm{pH}$ & $5.60 \pm 0.14^{a}$ & $6.80 \pm 0.06^{b}$ \\
\hline $\mathrm{EC}(1: 5)\left(\mathrm{mScm}^{-1}\right)$ & $12.50 \pm 0.13^{a}$ & $15.20 \pm 0.23^{b}$ \\
\hline Eh $(1: 1)(m V)$ & $24.00 \pm 1.15^{\mathrm{a}}$ & $18.00 \pm 0.23^{b}$ \\
\hline Organic C (\%) & $0.52 \pm 0.02^{\mathrm{a}}$ & $0.44 \pm 0.03^{\mathrm{a}}$ \\
\hline $\mathrm{PO}_{4}^{3-}\left(\mathrm{mg} \mathrm{kg}^{-1}\right)$ & $7.40 \pm 0.12^{\mathrm{a}}$ & $8.44 \pm 0.18^{b}$ \\
\hline Sand $(\%)$ & $59.30 \pm 2.77^{\mathrm{a}}$ & $61.18 \pm 0.69^{a}$ \\
\hline Silt (\%) & $19.20 \pm 0.17^{a}$ & $18.42 \pm 0.25^{\mathrm{a}}$ \\
\hline Clay (\%) & $23.50 \pm 0.52^{a}$ & $20.40 \pm 0.39^{b}$ \\
\hline Texture & Sandy loam & Sandy loam \\
\hline $\mathrm{CEC}\left(\mathrm{cmol} \mathrm{kg}^{-1}\right)$ & $12.80 \pm 0.52^{a}$ & $13.20 \pm 0.12^{\mathrm{a}}$ \\
\hline \multicolumn{3}{|l|}{ Total metals $\left(\mathrm{mg} \mathrm{kg}^{-1}\right)^{*}$} \\
\hline $\mathrm{Cd}$ & $7.60 \pm 0.23^{\mathrm{a}}$ & $7.20 \pm 0.06^{a}$ \\
\hline $\mathrm{Cr}$ & $6.80 \pm 0.06^{a}$ & $6.40 \pm 0.16^{b}$ \\
\hline $\mathrm{Cu}$ & $12.40 \pm 0.12^{\mathrm{a}}$ & $13.30 \pm 0.12^{\mathrm{a}}$ \\
\hline $\mathrm{Fe}$ & $88.90 \pm 2.66^{b}$ & $86.70 \pm 0.62^{\mathrm{a}}$ \\
\hline $\mathrm{Ni}$ & $9.40 \pm 0.58^{a}$ & $8.80 \pm 0.47^{a}$ \\
\hline $\mathrm{Pb}$ & $10.48 \pm 0.53^{a}$ & $11.55 \pm 0.47^{\mathrm{b}}$ \\
\hline $\mathrm{Zn}$ & $54.65 \pm 2.23^{b}$ & $58.20 \pm 0.24^{a}$ \\
\hline \multicolumn{3}{|c|}{ DTPA-extractable metals $\left(\mathrm{mg} \mathrm{kg}^{-1}\right)$} \\
\hline $\mathrm{Cd}$ & $0.88 \pm 0.06^{a}$ & $0.76 \pm 0.01^{a}$ \\
\hline $\mathrm{Cr}$ & $0.92 \pm 0.02^{\mathrm{a}}$ & $0.84 \pm 0.01^{b}$ \\
\hline $\mathrm{Cu}$ & $1.06 \pm 0.05^{\mathrm{a}}$ & $1.12 \pm 0.02^{\mathrm{a}}$ \\
\hline $\mathrm{Fe}$ & $17.89 \pm 0.78^{a}$ & $18.64 \pm 0.07^{\mathrm{a}}$ \\
\hline $\mathrm{Ni}$ & $2.08 \pm 0.04^{a}$ & $1.96 \pm 0.04^{\mathrm{a}}$ \\
\hline $\mathrm{Pb}$ & $3.58 \pm 0.17^{a}$ & $2.98 \pm 0.06^{b}$ \\
\hline $\mathrm{Zn}$ & $0.54 \pm 0.03^{a}$ & $0.48 \pm 0.01^{\mathrm{a}}$ \\
\hline
\end{tabular}

*Detectable limits of $\mathrm{Cd}, \mathrm{Cr}, \mathrm{Cu}, \mathrm{Fe}, \mathrm{Ni}, \mathrm{Pb}$ and $\mathrm{Zn}$ are $0.6 \mathrm{mg} \mathrm{L}^{-1}, 0.3 \mathrm{mg} \mathrm{L}^{-1}, 0.4 \mathrm{mg} \mathrm{L}^{-1}, 0.2 \mathrm{mg} \mathrm{L}^{-1}, 0.1 \mathrm{mg} \mathrm{L}^{-1}, 0.3 \mathrm{mg} \mathrm{L}^{-1}$ and $0.3 \mathrm{mg} \mathrm{L}^{-1}$ respectively).

Table 2: Concentration of heavy metals $\left(\mathrm{mg} \mathrm{kg}^{-1}\right)$ in leaf of $C$. fistula extracted by water and methanol(values represent mean of three replications $\pm \mathbf{S E}$, same letter(s) in a particulars column between two samples represent non-significant difference in particular element)

\begin{tabular}{|c|c|c|c|c|c|c|c|c|}
\hline Samples & Extractants & Cd & $\mathrm{Cr}$ & $\mathrm{Cu}$ & $\mathrm{Fe}$ & $\mathrm{Ni}$ & $\mathrm{Pb}$ & $\mathrm{Zn}$ \\
\hline \multirow[t]{2}{*}{ CF-MH } & Methanol & $\mathrm{ND}^{+}$ & ND & $2.13 \pm 0.07^{a}$ & $14.60 \pm 0.22^{\mathrm{a}}$ & ND & ND & $4.78 \pm 0.13^{a}$ \\
\hline & Water & ND & ND & $1.98 \pm 0.06^{c}$ & $11.34 \pm 0.04^{b}$ & ND & ND & $4.00 \pm 0.08^{c}$ \\
\hline \multirow[t]{2}{*}{ CF-KAR } & Methanol & ND & ND & $3.20 \pm 0.06^{b}$ & $15.30 \pm 0.62^{\mathrm{a}}$ & ND & ND & $5.62 \pm 0.24^{b}$ \\
\hline & Water & ND & ND & $2.12 \pm 0.02^{c}$ & $13.14 \pm 0.09^{c}$ & ND & ND & $4.48 \pm 0.28^{c}$ \\
\hline
\end{tabular}

${ }^{+} \mathrm{ND}$ : Not detectable (detectable limits of $\mathrm{Cd}, \mathrm{Cr}, \mathrm{Cu}, \mathrm{Fe}, \mathrm{Ni}$, Pband $\mathrm{Zn}$ are $0.6 \mathrm{mg} \mathrm{L}^{-1}, 0.3 \mathrm{mg} \mathrm{L}^{-1}, 0.4 \mathrm{mg} \mathrm{L}^{-1}, 0.2 \mathrm{mg} \mathrm{L}^{-1}, 0.1 \mathrm{mg} \mathrm{L}^{-1}, 0.3 \mathrm{mg} \mathrm{L}^{-1}$ and, $0.3 \mathrm{mg} \mathrm{L}^{-1}$ respectively). 
Table 3: Total phenol and antioxidant content in leaf extract of $\boldsymbol{C}$. fistula (values represent mean of three replications $\pm S E$, same letter(s) in a particulars column between

two samples represent non-significant difference in particular element represent)

\begin{tabular}{|c|c|c|c|c|c|}
\hline \multirow{2}{*}{ Sample ID } & Extractants & Total phenols & \multicolumn{3}{|c|}{ Antioxidant effect } \\
\cline { 4 - 6 } & & & $\begin{array}{c}\text { ORAC } \\
\text { (mmoleTrolox/g of } \\
\text { substance) }\end{array}$ & ABTS (\%) & IC $_{50}$ value \\
\hline \multirow{2}{*}{ CF-KAR } & Methanol & $12.15 \pm 0.09^{\mathrm{a}}$ & $743.0 \pm 1.2^{\mathrm{a}}$ & $56.2 \pm 1.2^{\mathrm{a}}$ & $60.2 \pm 0.8^{\mathrm{a}}$ \\
\cline { 2 - 6 } & Water & $9.38 \pm 0.10^{\mathrm{c}}$ & $660.0 \pm 17.9^{\mathrm{c}}$ & $16.2 \pm 0.4^{\mathrm{c}}$ & - \\
\hline \multirow{2}{*}{ CF-MH } & Methanol & $18.54 \pm 1.02^{\mathrm{b}}$ & $812.0 \pm 1.7^{\mathrm{b}}$ & $66.5 \pm 2.4^{\mathrm{b}}$ & $51.4 \pm 0.9^{\mathrm{b}}$ \\
\cline { 2 - 6 } & Water & $13.14 \pm 0.09^{\mathrm{d}}$ & $686.0 \pm 13.9^{\mathrm{d}}$ & $33.2 \pm 0.2^{\mathrm{d}}$ & $58.2 \pm 0.6$ \\
\hline
\end{tabular}

${ }^{\dagger}$ Total phenol content was expressed as $\mathrm{mg}$ of gallic acid g-10f dry sample.

Assuming Unequal Population Variances/Standard Deviations $\left(\sigma_{1}^{2} \neq \sigma_{2}^{2}\right)$

The test statistic is

$$
t=\frac{\bar{x}_{1}-\bar{x}_{2}}{\operatorname{SE}\left(\bar{x}_{1}-\bar{x}_{2}\right)}=\frac{\bar{x}_{1}-\bar{x}_{2}}{\sqrt{\frac{s_{1}^{2}}{n_{1}}+\frac{s_{2}{ }^{2}}{n_{2}}}} \sim \mathrm{t}-
$$

distribution $\mathrm{df}=\min \left(\mathrm{n}_{1}-1, \mathrm{n}_{2}-1\right)$

The results were expressed as mean $\pm \operatorname{SD}(n=3)$.

The statistical analysis was performed repeated ANOVA with post "Dunnett's Multiple Comparison Test" for phenol content in the extracts and further more correlation matrix determined at confidence intervals 95\% with two trialed where the $\mathrm{p}$ value at $<0.05$ was considered as statistically significant. The data were processed with Microsoft excel.

\section{RESULTS}

\section{Physical and chemical properties of soils}

Selected physical and chemical properties of two experimental sites have been tabulated in Table 1. The physical and chemical properties of experimental soils were appeared to be location dependent. $\mathrm{pH}$ levels of $\mathrm{CF}-\mathrm{MH}$ was more acidic that CF-KAR. Like $\mathrm{pH}, \mathrm{EC}$ was found significantly higher in CF-KAR that CF-MH $(\mathrm{p} \leq 0.05)$. However, Eh value was higher in soil collected from Chandgad district than Bangalore. There was no significant difference found in organic carbon between the soils. Phosphate contents in experimental soils were varied between $7.40 \pm 0.12$ and $8.44 \pm 0.18 \mathrm{mg} \mathrm{kg}$. Texturally soils were found sandy loam in nature. Even though organic carbon and clay percent in $\mathrm{MH}$ was higher than KAR, CEC of CF-KAR was higher that $\mathrm{MH}$. Total metals content in soils was followed the following trend $\mathrm{Fe}>\mathrm{Cu}>\mathrm{Ni}>\mathrm{Zn}>\mathrm{Pb}>\mathrm{Cd}>\mathrm{Cr}$ irrespective of location. The trend of DTPA extractable metals in soils was found $\mathrm{Fe}>\mathrm{Pb}>\mathrm{Ni}>\mathrm{Cu}>\mathrm{Cr}>\mathrm{Cd}>\mathrm{Zn}$.

\section{Distribution pattern and risk assessment code (RAC) of heavy metals in soils}

The six step chemical fractionation of heavy metals in the soil samples has been depicted in Figure 2A and B for $\mathrm{MH}$ and $\mathrm{KAR}$ respectively, where each fraction has been represented as the percent of total individual metals. Among the six fractions of metals, the first three fractions (the sum of the water-soluble, exchangeable, and carbonate fractions) are considered as mobile factions which are and potentially bio available.,.$^{2,13,38}$ and other three fractions (e.g. Fe-Mn oxides; organically and residual fractions) are considered as immobile factions which are and potentially unavailable towards soil organisms and plants. The heavy metals associated with different fractions in Maharashtra series (sample ID: $\mathrm{MH}$ ) follow the order: Cd: F6 (4.41 mg kg-1) > F5 (2.04 $\left.\mathrm{mg} \mathrm{kg}^{-1}\right)>$ F4 (0.75 $\left.\mathrm{mg} \mathrm{kg}{ }^{-1}\right)>\mathrm{F} 3\left(0.26 \mathrm{mg} \mathrm{kg}^{-1}\right)>\mathrm{F} 2\left(0.09 \mathrm{mg} \mathrm{kg}^{-1}\right)>\mathrm{F} 1$ $\left(0.06 \mathrm{mg} \mathrm{kg}^{-1}\right)$;

Cr: F6 (4.81 $\left.\mathrm{mg} \mathrm{kg}^{-1}\right)>\mathrm{F} 4\left(1.00 \mathrm{mg} \mathrm{kg}^{-1}\right)>\mathrm{F} 5(0.81$ $\left.\mathrm{mg} \mathrm{kg}^{-1}\right)>\mathrm{F} 2\left(0.08 \mathrm{mg} \mathrm{kg}^{-1}\right)>\mathrm{F} 3\left(0.07 \mathrm{mg} \mathrm{kg}^{-1}\right)>\mathrm{F} 1(0.02$ $\left.\mathrm{mg} \mathrm{kg}{ }^{-1}\right)$;

Cu: F6 (6.76 mg kg-1) > F4 (2.65 mg kg-1) > F5 (2.19 $\left.\mathrm{mg} \mathrm{kg}{ }^{-1}\right)>\mathrm{F} 3\left(0.54 \mathrm{mg} \mathrm{kg}^{-1}\right)>\mathrm{F} 2\left(0.17 \mathrm{mg} \mathrm{kg}^{-1}\right)>$ F1(0.09 $\left.\mathrm{mg} \mathrm{kg}^{-1}\right)$;

Fe: F5 (34.65 $\left.\mathrm{mg} \mathrm{kg}^{-1}\right)>$ F6 $\left(28.22 \mathrm{mg} \mathrm{kg}^{-1}\right)>$ F3 (11.34 $\left.\mathrm{mg} \mathrm{kg}{ }^{-1}\right)>\mathrm{F} 4\left(10.47 \mathrm{mg} \mathrm{kg}^{-1}\right)>\mathrm{F} 1\left(2.45 \mathrm{mg} \mathrm{kg}^{-1}\right)>\mathrm{F} 2$ $\left(1.76 \mathrm{mg} \mathrm{kg}^{-1}\right)$;

Ni: F6 $\left(4.77 \mathrm{mg} \mathrm{kg}^{-1}\right)>$ F5 $\left(2.77 \mathrm{mg} \mathrm{kg}^{-1}\right)>\mathrm{F} 4(1.37$ $\left.\mathrm{mg} \mathrm{kg}{ }^{-1}\right)>\mathrm{F} 2\left(0.20 \mathrm{mg} \mathrm{kg}^{-1}\right)>\mathrm{F} 3\left(0.19 \mathrm{mg} \mathrm{kg}^{-1}\right)>\mathrm{F} 1$ $\left(0.10 \mathrm{mg} \mathrm{kg}^{-1}\right)$;

Pb: F6(5.64 mg kg-1) > F4(2.43 $\left.\mathrm{mg} \mathrm{kg}^{-1}\right)>\mathrm{F} 5(2.07$ $\left.\mathrm{mg} \mathrm{kg}{ }^{-1}\right)>\mathrm{F} 3\left(0.14 \mathrm{mg} \mathrm{kg}{ }^{-1}\right)>\mathrm{F} 1\left(0.11 \mathrm{mg} \mathrm{kg}^{-1}\right)>$ F2 $\left(0.09 \mathrm{mg} \mathrm{kg}^{-1}\right)$;

Zn: F1 $\left(0.72 \mathrm{mg} \mathrm{kg}^{-1}\right)>\mathrm{F} 2\left(1.20 \mathrm{mg} \mathrm{kg}^{-1}\right)>\mathrm{F} 3(0.96$ $\left.\mathrm{mg} \mathrm{kg}{ }^{-1}\right)>\mathrm{F} 4\left(15.73 \mathrm{mg} \mathrm{kg}^{-1}\right)>\mathrm{F} 5\left(12.02 \mathrm{mg} \mathrm{kg}^{-1}\right)>$ F6(24.02 $\left.\mathrm{mg} \mathrm{kg}^{-1}\right)$. 
For Bangalore series (sample ID: KAR), the heavy metals associated with different fractions follow the order:

Cd: F6(3.91 mg kg-1) > F5(2.07 mg kg-1) > F3(0.63 $\left.\mathrm{mg} \mathrm{kg}{ }^{-1}\right)>\mathrm{F} 4\left(0.57 \mathrm{mg} \mathrm{kg} \mathrm{kg}^{-1}\right)>\mathrm{F} 2\left(0.01 \mathrm{mg} \mathrm{kg}^{-1}\right)>$ F1 $\left(0.00 \mathrm{mg} \mathrm{kg}^{-1}\right)$;

Cr: F6(3.57 mg kg-1) $>$ F5(1.36 mg kg-1) $>$ F4 $(0.70$ $\left.\mathrm{mg} \mathrm{kg}{ }^{-1}\right)>\mathrm{F} 3\left(0.63 \mathrm{mg} \mathrm{kg}^{-1}\right)>\mathrm{F} 1\left(0.08 \mathrm{mg} \mathrm{kg}^{-1}\right)>\mathrm{F} 2$ $\left(0.06 \mathrm{mg} \mathrm{kg}^{-1}\right)$;

Cu: F6 $\left(7.82 \mathrm{mg} \mathrm{kg}^{-1}\right)>\mathrm{F} 4\left(2.63 \mathrm{mg} \mathrm{kg}^{-1}\right)>\mathrm{F} 5(2.50$ $\mathrm{mg} \mathrm{kg}-1)>\mathrm{F} 2\left(0.16 \mathrm{mg} \mathrm{kg}^{-1}\right)>\mathrm{F} 3\left(0.14 \mathrm{mg} \mathrm{kg}^{-1}\right)>$ F1 $\left(0.04 \mathrm{mg} \mathrm{kg}^{-1}\right)$;

Fe: F6(38.46 $\left.\mathrm{mg} \mathrm{kg}^{-1}\right)>$ F5 (17.15 $\left.\mathrm{mg} \mathrm{kg}^{-1}\right)>$ F3 $(15.42$ $\left.\mathrm{mg} \mathrm{kg}{ }^{-1}\right)>\mathrm{F} 4\left(14.36 \mathrm{mg} \mathrm{kg}^{-1}\right)>\mathrm{F} 1\left(0.69 \mathrm{mg} \mathrm{kg}^{-1}\right)>\mathrm{F} 2$ $\left(0.62 \mathrm{mg} \mathrm{kg}^{-1}\right)$;

Ni: F6 $\left(4.02 \mathrm{mg} \mathrm{kg}^{-1}\right)>$ F5 $\left(2.64 \mathrm{mg} \mathrm{kg}^{-1}\right)>$ F3 $(1.26$ $\mathrm{mg} \mathrm{kg}-1)>\mathrm{F} 4\left(0.86 \mathrm{mg} \mathrm{kg}^{-1}\right)>\mathrm{F} 1\left(0.01 \mathrm{mg} \mathrm{kg}^{-1}\right) \approx \mathrm{F} 2$ $\left(0.01 \mathrm{mg} \mathrm{kg}^{-1}\right)$;

Pb: F6 (4.93 mg kg-1) > F5 (3.98 $\left.\mathrm{mg} \mathrm{kg}^{-1}\right)>$ F3 $(1.13$ $\left.\mathrm{mg} \mathrm{kg}{ }^{-1}\right)>$ F4 $\left(1.10 \mathrm{mg} \mathrm{kg}^{-1}\right)>\mathrm{F} 2\left(0.27 \mathrm{mg} \mathrm{kg}^{-1}\right)>\mathrm{F} 1$ $\left(0.14 \mathrm{mg} \mathrm{kg}^{-1}\right)$ and

Zn: F6 $\left(17.33 \mathrm{mg} \mathrm{kg}^{-1}\right)>$ F4 $\left(13.25 \mathrm{mg} \mathrm{kg}^{-1}\right)>$ F5 (12.68 $\left.\mathrm{mg} \mathrm{kg}^{-1}\right)>$ F3 $\left(11.51 \mathrm{mg} \mathrm{kg}^{-1}\right)>$ F2 $\left(1.99 \mathrm{mg} \mathrm{kg}^{-1}\right)>$ F1 $\left(1.44 \mathrm{mg} \mathrm{kg}^{-1}\right)$.

The calculated risk assessment code (RAC) based on fractionation analysis has been depicted in Figure 3. The RAC value for soil $\mathrm{MH}$ ranged between $2.5 \pm 0.08$ (for $\mathrm{Cr}$ ) and $6.5 \pm 0.32$ (for $\mathrm{Cu}$ ). However it was ranged between $2.6 \pm 0.09$ (for $\mathrm{Cu}$ ) and $25.7 \pm 0.40$ (for $\mathrm{Zn}$ ) for KAR.

\section{Yield of the leaf extracts}

The yield of the leaf extracts are presented in Figure 4. The Figure described that the methanolic extract of C. fistula leaf given higher yield $(17.3 \%$ and $16.0 \%$ for CF-MH and CF-KAR respectively) than aqueous extract $(14.9 \%$ and $14.8 \%$ for CF-MH and CF-KAR respectively) for both the samples but marginal nonsignificant differences observed between them when compared with the geographical sources.

\section{Metal in leaf extracts}

The mean concentration levels of metals in methanol and water extracts of the leaf are summarized in Table 2. A perusal of the data in Table 2 shows that only $\mathrm{Cu}$, $\mathrm{Fe}$ and $\mathrm{Zn}$ were found in leaf extracts, but no results were found for non-essential heavy metals like $\mathrm{Ni}, \mathrm{Cd}$, $\mathrm{Cr}$ and $\mathrm{Pb}$ for both the samples. Among the extracts methanolic extract from CF-KAR showed comparatively better when compared with elemental contents of the CF-MH sample. In general the mineral contents in analyzing extracts are in wide range and trend of metals followed $\mathrm{Fe}>>\mathrm{Zn}>\mathrm{Cu}$. The value of $\mathrm{Cu}$ varied in a range of $1.98 \pm 0.06-3.20 \pm 0.06 \mathrm{mg} \mathrm{kg}^{-1}$. For Fe and $\mathrm{Zn}$, the ranges were $11.34 \pm 0.04-15.30 \pm 0.62$ and 4.00 \pm 0.08 to $5.62 \pm 0.24 \mathrm{mg} \mathrm{kg}^{-1}$ respectively.

\section{Total phenolic content and antioxidant studies}

Total phenolic content and subsequent antioxidant study of the two different extracts were carried out and the data were tabulated in Table 3. Methanolic extracts of both the samples were determined higher than aqueous extracts and calculated $18.54 \mathrm{mg} \mathrm{g}^{-1}$ (metahnolic sample of $\mathrm{CF}-\mathrm{MH}$ ) of dry sample when compared with the standard Gallic acid and all the results showed significant. Furthermore interesting point noticed when elemental contents were determined. All the major microelements, viz. $\mathrm{Fe}, \mathrm{Zn}, \mathrm{Cu}$ and some heavy metals like $\mathrm{Ni}, \mathrm{Cd}, \mathrm{Cr}$ and $\mathrm{Pb}$ were determined to correlate the effects on total phenolic content and antioxidant study. Significant correlation drawn from the essential elements with total phenolic and antioxidant study but no heavy metals was detected for both the samples. Methanolic extracts from CF-MH showed statistical significant results than aqueous extracts.

\section{DISCUSSION}

\section{Physical and chemical properties of soils}

Soil acidity as $\mathrm{pH}$ indicating that experimental soil in the study areas was slightly acidic to neutral soils. High EC values may reflect the considerable amount of soluble salts in soils, and high EC values in soils may impede the growth of agricultural crops as suggested by Chai et al. (2015).$^{38}$ Relatively low organic carbon in experimental soils suggested that the soils are not fertile under the favorable environmental conditions. Even though soil $\mathrm{MH}$ contains a comparatively higher amount of organic carbon and clay than soil KAR, CEC of KAR was found significantly higher than $\mathrm{MH}$. The lower CEC of $\mathrm{MH}$ as compare to KAR could be due to the presence of the lower amount of humified carbon in $\mathrm{MH}$ that decreased the formation of carboxyl and phenolic functional groups, which in turn, contributed to lower CEC (Karak et al., 2014). ${ }^{14}$ All the heavy metals reported in this study are necessary for several physiological functions in trace amount of plant and other organism, but their elevated concentrations could have an adverse effect. ${ }^{3}$ Furthermore, metals in experimental soils originate from natural sources, viz. parent materials from which the soils developed. ${ }^{39}$ and anthropogenic sources includes atmospheric deposition, road side runoff and industrial waste discharges. ${ }^{36}$ According to Kabata-Pendias and Pendias (2011), ${ }^{3}$ world average concentrations of $\mathrm{Cd}, \mathrm{Cr}, \mathrm{Cu}, \mathrm{Fe}, \mathrm{Ni}, \mathrm{Pb}$ and $\mathrm{Zn}$ in 
uncontaminated soils are $0.41,59.5,38.9,50,29,27$ and $70 \mathrm{mg} \mathrm{kg}^{-1}$ respectively. Therefore, the investigated soils can be regarded as uncontaminated by analysed metal except $\mathrm{Cd}$, as the total amount of $\mathrm{Cd}$ was within the range between $7.20 \pm 0.06$ and $7.60 \pm 0.23 \mathrm{mg} \mathrm{kg}^{-1}$. Juwarkar et al., (2007)..$^{40}$ reported that the average $\mathrm{Cd}$ concentration in natural soils of India was found 16.5 $\mathrm{mg} \mathrm{kg}^{-1}$, which is around 30 times lower than contaminated urban soils in India. They concluded that elevated a concentration of $\mathrm{Cd}$ is urban soils could be due to accumulation of $\mathrm{Cd}$ bearing road dust in the top soil of roadside areas. Karak et al (2013a). ${ }^{2}$ also concluded that road dust is an increasing problem for heavy metals in developing countries like India. However, the concentrations of reported metals in roadside soils were generally on the lower side when compared with available data in the reported literatures., ${ }^{240-42}$ It must be pointed out that the DTPA extractable $\mathrm{Cd}, \mathrm{Cr}, \mathrm{Cu}, \mathrm{Fe}$, $\mathrm{Ni}, \mathrm{Pb}$ and $\mathrm{Zn}$ in soils contributed 10.6-11.6\%, 13.1$13.5 \%, 8.4-8.5 \%, 21.5-20.1 \%, 22.3-22.1 \%, 25.8-34.2 \%$ and $0.8-1.0 \%$, of total individual metal respectively. For all metals, soil KAR showed higher percent of DTPA extractable metals than soil MH. Cooperatively lower percent of DTPA extractable metals in soils indicated that the experimental soils contain fewer amounts of potentially plant available metals. Furthermore, the small ratios of DTPA extractable metals with respect to total metal can't identify the role of climatic conditions, soil genesis, geological and vegetation history in the development of those extractable metals in soils.

\section{Distribution pattern and risk assessment code (RAC) of heavy metals in soils}

It has been hypothysed that either DTPA extractable metals or the sum of first three fractions of metals through a sequential extraction procedure (i.e. $\mathrm{F} 1+\mathrm{F} 2+\mathrm{F} 3$ ) represent the labile pool of metals in soils. ${ }^{13}$ Therefore, their linear correlation ship should exist. In the present study, a statistically significant correlation between DTPA-extractable metals and the labile pool of in experimental soils was found, indicating a close association between them $\left(\mathrm{r}^{2}\right.$ values for $\mathrm{Cd}, \mathrm{Cr}, \mathrm{Cu}, \mathrm{Fe}, \mathrm{Ni}, \mathrm{Pb}$ and $\mathrm{Zn}$ in $\mathrm{MH}$ were $0.97,0.89,0.93,0.91,0.88,0.90$ and 0.97 respectively and those are $0.92,0.99,0.96,0.93$, $0.88,0.87$ and 0.96 for KAR). This further confirm the hypothesis that DTPA extractable metals and first three fraction of metals through sequential extraction release only the weakly bound elements present in soil structure. Acosta et al., (2015), ${ }^{43}$ also reported a highly significant correlation between the DTPA-extractable contents and the labile fraction of trace elements. To support this hypothesis, Karak et al (2011) ${ }^{13}$ concluded that DTPA might be used to estimate the mobile element fraction, instead of the more costly and time consuming sequential extractions even though sequential extractions give a more informative picture of metal partitioning among different phases. Irrespective of study metals, organically bound metals in $\mathrm{MH}$ was considerable higher than KAR. This could be due to higher Eh of $\mathrm{MH}$ than KAR as higher Eh of soil can degrade metals bound in organic matter as suggested by Feng et al (2009). ${ }^{44}$ The mobility sequence of the metals based on the sum of the proportions of first three fraction i.e. water-soluble, exchangeable and bound to carbonates for $\mathrm{MH}$ were in the order: $\mathrm{Fe}(17.5 \%)>\mathrm{Cu}(6.45 \%)>\mathrm{Cd}(5.38 \%)>\mathrm{Zn}$ $(5.27 \%)>\mathrm{Ni}(5.21 \%)>\mathrm{Pb}(3.17 \%)>\mathrm{Cr}(2.47 \%)$ and the order for KAR: $\mathrm{Zn}(25.68 \%)>\mathrm{Fe}(19.30 \%)>\mathrm{Ni}$ $(14.53 \%)>\mathrm{Pb}(13.32 \%)>\mathrm{Cr}(11.99 \%)>\mathrm{Cd}(8.93 \%)$ $>\mathrm{Cu}(2.60 \%)$. It could be noted that all the metals in experimental soils are present in potentially non-mobile phases and, therefore, these elements can be considered to be the less readily mobilized and bioavailable elements in urban soil. A similar observation was reported by Subramanian et al. (2015). ${ }^{45}$ when metals were analyzed in street dusts in India. The studied soils contained low organic carbon that could increase the metal availability due formation of free metal ion without complexion. Significantly low amounts of organically bound metal in experimental soil as well as higher amount in residual fraction are the important sinks for metals in the soils. These findings are similar to the results reported by Pandey et al. (2015). ${ }^{46}$ when geochemical speciation of selected metals using a three-stage sequential extraction procedure was performed in the sediments collected from river Ganga sediment at Varanasi of India.

To gain additional insights for assessment of heavy metal pollution and their associated environmental risk, risk assessment code (RAC) has been calculated based on the protocol described by several researchers. ${ }^{37,47,48}$ From the experimental data, it has been clearly observed that analyzed metals in soils are bound to different fraction having different strength which is an indication of soil reactivity reflecting the metal release risk in soil solution as well as their uptake pattern by growing plants. According to RAC protocol for any metals, soil which can release less than $1 \%$ of the total metal will be considered no risk, $1-10 \%$ of the total metal will be considered low risk, $>10-30 \%$ of the total metal will be considered medium risk, $>30-50 \%$ of the total metal will be considered high risk and $>50 \%$ of the total metal will be considered very high risk. ${ }^{37}$ This classification has also been presented in Figure 3. From Figure 3 it can be found that the concentrations of all the reported metals in $\mathrm{MH}$ are posing a low risk to the soil environment. 
However, for KAR only $\mathrm{Cd}$ and $\mathrm{Cu}$ poses low risk, but other metals are posing a medium risk to the soil environment. $\mathrm{Zn}$ and $\mathrm{Fe}$ for are considered as essential elements for plant, therefore, KAR soil can provide those elements to growing plants. The similar results have been documented by Sundaray et al. $(2011)^{49}$ when RAC was assessed in the Mahanadi river estuarine sediments in India. Similarly, Zhao et al. $(2007)^{50}$ concluded that the concentrations of $\mathrm{Cr}$ and $\mathrm{Ni}$ were strongly associated with $\mathrm{Al}$ and $\mathrm{Fe}$ fraction in soils collected from England and Wales, and therefore Al-Fe fraction in the experimental soils can be used to predict ambient background concentrations of trace metals in soils.

\section{Yield of the extracts}

The leaf extract of $C$. fistula with different solvents, viz., methanol, benzene and acetone has been documented against several diseases like Chikungunya, 51 liver disorders, antimicrobial, purgative, astringent, hemorrhoids, rheumatism, ulcers and jaundice. ${ }^{9,52}$ Siddhuraju et al. (2002). ${ }^{7}$ reported that higher amount of crude extracts from the leaf of $C$. fistula might be attributed to the presence of a high proportion of soluble sugars. The present findings also support the reported results of Govindarajan (2009) ${ }^{51}$ when leaf samples of C. fistula were collected from Thanjavur District, Tamil Nadu, India. The author also concluded that the crude plant extracts measurement of medicinal plant getting paramount importance now a day as these extracts often consist of a complex mixture of active compounds and this mixture shows greater bioactivity compared to the individual constituents. On the contrary, Sowndhararajan and Kang (2013). ${ }^{53}$ reported that the maximum extract yield was obtained in the hot water $(6.3 \%)$ followed by methanol $(5.9 \%)$ from Baubinia vablii leaves collected from Coimbatore, Tamil Nadu state in India.

\section{Metal in the leaf extracts}

Several medicinal plants can accumulate metals from growing media and a copious number of plants have been documented to have phyto remediation properties by several authors. ${ }^{54-56}$ As leaf extract of $C$. fistula has been used for healing from several diseases, therefore, heavy metals in leaf extracts need a thorough investigation to prevent elevated concentrations of heavy metals reaching the consumer. ${ }^{6}$ High amount of $\mathrm{Fe}$ in C. fistula supported the finding of Devi and Sarma (2010) ${ }^{57}$ where the authors reported that the Fe content in seven medicinal plants collected from various areas of Manipur, a north-eastern state of India. Essential metal contents in CF-KAR could be due to the presence of highly mobile phase of metal in soil KAR. Gregor (2004) $)^{58}$ reported several abiotic factors influence the availability of metal to plants, including $\mathrm{pH}$, temperature, redox potential, cation exchange capacity and organic matter. Similarly, Karak et al. (2015). ${ }^{15}$ reported that, the interactions of soil-plant roots-microbes play vital roles in regulating metal movement from the soil to edible plant parts.

\section{Total phenolic content and antioxidant studies}

With respect to phenolic content in the plant, the present study clearly demonstrated that the sample collected from CF-MH showed better results than CF-KAR. These results may be due to the interaction between the environmental conditions because low temperature with high acidic soil nature may increase production of total phenolic by enhancing the synthesis of phenylalanine ammonia lyase in plants. ${ }^{59}$ Furthermore, the recovery of phenolic content in plant leaf samples is influenced by the polarity of extracting solvents and solubility of the compound in the solvent used for extraction. ${ }^{60}$ that same principle followed in the present study where methanolic extract showed better results. Further the antioxidant potential of phenolics depends on the number and arrangement of the hydroxyl groups. ${ }^{61}$ In phenolic acids, the freer $-\mathrm{OH}$ groups in the ring shows the larger TEAC (Trolox Equivalent Antioxidant Capacity) value is with ABTS and ORAC methods. ${ }^{62}$ By looking at this mechanism higher phenolic content was resulted with the methanolic extracts of both the samples and hence antioxidant results also proportionally increased with respect to total phenolics contents. Fresco et al., (2006), ${ }^{63}$ reported that phenolics are powerful antioxidants and act in a structure-dependent manner; they can scavenge reactive oxygen species, and chelate transition metals which play vital roles in the initiation of deleterious free radical reactions. Oxygen radical absorbance capacity (ORAC) assay is gaining popularity in agricultural and nutritional sciences as it reflects the scavenging capacity of compounds with antioxidant activity against free radicals. ${ }^{64,65}$ Furthermore, Deng et al (2014). ${ }^{26}$ reported that ORAC assay has been frequently used to demonstrate variations in the antioxidant properties of leaf and fruit as well as vegetable extracts. Table 3 shows the ORAC of in leaf extract of $C$. fistula as $\mu \mathrm{mol}$ Trolox/g of substance. ORAC in CF-MH was found significantly higher $(p>0.05)$ that $C F-K A R$ irrespective of solvent. Methanol extracts of leaves exhibited significantly higher ORAC values $(p<0.05)$ than the water extract. This finding also in agreement with Złotek et al (2015). ${ }^{66}$ when the effect of different solvents extracted ORAC of basil leaves (Ocimum basilicum L.) has been documented. Fu et al (2014), ${ }^{67}$ also reported that ORAC values of ethanol-insoluble fraction of water extract of 
Sapium sebiferum (L.) Roxb. leaves were between $3.00 \pm$ $0.12 \mu \mathrm{mol}$ Trolox $/ \mathrm{mg}$ and $3.33 \pm 0.07 \mu \mathrm{mol}$ Trolox $/ \mathrm{mg}$. According to Huang et al. (2012), ${ }^{68} 80 \%$ methanol extracts showed significant higher ORAC than those of hot water extracts in different tea leaves (Camellia sinensis L.) extracts, this is because the responsible antioxidant components are more easily extracted in aqueous organic solvent than that of hot water. The significantly higher ORAC value of leave sample collected from Chandgad District, Kolhapur, Maharashtra (sample ID: CF-MH) than leave sample collected from Bangalore, Karnataka (sample ID: CF-KAR), indicating that leave collected from Maharashtra had higher antioxidant capacity.

\section{Statistical Interpretations}

The analysis revealed that hypothesis of equal variances for Zn_THM, Fe_DTPA, Zn_DTPA, F1_Cd, F2_Cd, F3_Cd, F6_Cd, RAC_Cd, F1_Cr, F3_Cr, F3_Cu, F1_ Fe, F2_Fe, F3_Ni, F6_Ni, F2_Pb, F5_Zn and Methanol_TP were rejected indicating that the population variances were unequal in the above cases. Accordingly, two sample t-test with unequal variances was applied to check for any presence of significance difference of the above elements between two places. In all other elements t-test with equal variance was applied. The results of the analysis are depicted in Table 1 to 3. A perusal of Table 1 to 3 indicates that the content of some of the elements significantly differs between two samples and some elements does not differ. The content of organic C, sand, silt, CEC differs significantly in Maharastra and Karnataka. Among the DTPA extractable elements, except for $\mathrm{Cr}$ and $\mathrm{Pb}$, the content of all other elements do not differ significantly in two places. When the concentration of heavy metals in leaf samples extracted by water and methanol was analyzed it was found that; in methanol extraction, $\mathrm{Cu}$ and $\mathrm{Zn}$ differ significantly where as the Fe content is found to be same in both the places; in water extraction, only Fe content differs significantly in two places. As far as total phenol and antioxidant content in leaf extract is concerned, the samples from two places differ significantly.

\section{CONCLUSIONS}

The present study has endowed the effect of micro elements especially heavy metals on total phenolic content vis-à-vis on antioxidant activity. The risk assessment code (RAC) was found between low risk and medium risk of pollution with respect to metal concentration. However, metal concentration in leaf extracts of C. fistula corroborated the hypothesis that roots act as a buffer and hold back contamination from the aerial parts. Furthermore the results revealed the significant variation of metal concentration in leaf extracts with respect to locations. The highest antioxidant activity as well as total phenols was found in methanoilc extract of leaf irrespective of locations. Interestingly, the soil $\mathrm{pH}$ also played a major role for enhanced element contains which in turn would support the plant growth in a sustained way for antioxidant activity. Analysis revealed that the higher level of essential heavy metals combined with methanolic extract was relatively higher for $\mathrm{CF}-\mathrm{MH}$ and closely followed by CF-KAR, having no significant differences.

\section{ACKNOWLEDGEMENT}

Authors are thankful of Prof. Dilip Kumar Das, Emeritus Fellow (UGC), Department of Agricultural Chemistry and Soil Science Institute of Agricultural Science, University of Calcutta, West Bengal, for analysis of heavy metals for our soil samples. Further extended great support to the St. John's Pharmacy college management for provided financial support of Rs. 30,000/to carry out the whole research.

\section{CONFLICT OF INTEREST}

Authors are declared as no conflict of Interest.

\section{REFERENCES}

1. Sinha S, Mallick S, Misra RK, Singh S, Basant A and Gupta AK. Uptake and translocation of metals in Spinacia oleracea L. grown on tannery sludgeamended and contaminated soils: Effect on lipid peroxidation, morphoanatomical changes and antioxidants. Chemosphere. 2007;67(1):176-87.

2. Karak T, Bhattacharyya P, Paul RK and Das DK. Metal accumulation, biochemical response and yield of Indian mustard grown in soil amended with rural roadside pond sediment. Ecotoxicol Environ Saf. 2013;92:161-73.

3. Kabata-Pendias A and Pendias H. Trace Elements in Soils and Plants, $4^{\text {th }}$ edition CRC Press, Boca Raton, FL.2011.

4. Karak T, Bhattacharyya P, Das T, Paul RK and Bezbaruah R. Non-segregated municipal solid waste in an open dumping ground: A potential contaminant in relation to environmental health. Int J Environ Sci Technol. 2013;10(3):503-18.

5. Singh RP and Agrawal M. Effects of sewage sludge amendment on heavy metal accumulation and consequent responses of Beta vulgaris plants. Chemosphere. 2007;67(11):2229-40.

6. Street RA. Heavy metals in medicinal plant products - An African perspective. S Afr J Bot. 2012;82:67-74.

7. Siddhuraju P, Mohan PS and Becker K. Studies on the antioxidant activity of Indian Laburnum (Cassia fistula L.): a preliminary assessment of crude extracts from stem bark, leaves, flowers and fruit pulp. Food Chem. 2002;79(1):61-7.

8. Duraipandiyan $\mathrm{V}$ and Ignacimuthu $\mathrm{S}$. Ethno pharmacological communication Antibacterial and antifungal activity of Cassia fistula L.: An ethno medicinal plant. J Ethno Pharmacol. 2007;112:590-4.

9. Gairola S, Sharma J, Bedi YS. A cross-cultural analysis of Jammu, Kashmir and Ladakh (India) medicinal plant use. J Ethno Pharmacol. 2014;155(2):925-36.

10. Alam MM, Siddiqui MB, Hussian, W. Treatment of diabetes through herbal drugs in rural India. Fitoterpia. 1990;61(3):240-2.

11. Bahorun T, Neergheen VS and Aruoma OI. Phytochemical constituents of Cassia fistula. Afr J Biotechnol. 2005;4(13):1530-40. 
12. Karak T, Bhattacharyya P, Paul RK, Das T and Saha SK. Evaluation of composts from agricultural wastes with fish pond sediment as bulking agent to improve compost quality. CLEAN-Soil, Air, Water. 2013;41(7):711-23.

13. Karak T, Abollino O, Bhattacharyya P, Das KK and Paul RK. Fractionation and speciation of arsenic in three tea gardens soil profiles and distribution of as in different parts of tea plant (Camellia sinensis L.). Chemosphere. 2011;85(6):948-60.

14. Karak T, Paul RK, Sonar I, Sanyal S, Ahmed KZ, Boruah RK, et al. Chromium in soil and tea (Camellia sinensis L.) infusion: Does soil amendment with municipal solid waste compost make sense? Food Res Int. 2014;64:114-24.

15. Karak T, Sonar I, Paul RK, Frankowski M, Boruah RK, Dutta A K, et al. Aluminium dynamics from soil to tea plant (Camellia sinensis L.): Is it enhanced by municipal solid waste compost application? Chemosphere. 2015;119:917-26.

16. Kelly RA, Andrews JC and Dewitt JG. An X-ray absorption spectroscopic investigation of the nature of the zinc complex accumulated in Datura innoxia plant tissue culture. Microchem J. 2002;71(2-3):231-45.

17. Bhattacharjee $S$, Kar S and Chakravarty S. Mineral compositions of datura: a traditional tropical medicinal plant. Commun Soil Sci Plant Anal. 2004;35(7-8): 937-46.

18. Nkoane BBM, Sawula GM, Wibetoe G and Lund W. Identification of $\mathrm{Cu}$ and $\mathrm{Ni}$ indicator plants from mineralised locations in Botswana. J Geochem Explor. 2005;86(3):130-42.

19. Okem A, Southway C, Stirk WA, Street RA, Finnie JF and Van Staden J. Heavy metal contamination in South African medicinal plants: A cause for concern. S Afr J Bot. 2014;93:125-30.

20. ATSDR. Agency for Toxic Substances and Disease Registry. Toxicological Profile for Cadmium and Nickel. US Department of Health and Human Services. Public Health Service. 1999;205:93-0606.

21. ATSDR. Agency for Toxic Substances and Disease Registry. Toxicological profile for lead (update). Atlanta: US Department of Health and Human Services; 1999b. Contract No:205-93-0606.

22. ATSDR. Agency for Toxic Substances and Disease Registry, Toxicological profile for zinc (update). Atlanta; US Department of Health and Human Services; Contract No: 1994;205:88-0608

23. Tarricone K, Wagner $\mathrm{G}$ and Klein R. Toward standardization of sample collection and preservation for the quality of results in bio monitoring with trees - A critical review. Ecol Indic. 2015;57:341-59.

24. Rubio R and Ure AM. Approaches to sampling and sample pretreatments for metal speciation in soils and sediments. Int J Environ Anal Chem. 1993;51 (1-4):205-17.

25. Pourmorad F, Hosseinimehr SJ and Shahabimajd N. Antioxidant activity, phenols and flavonoids contents of some selected Iranian medicinal plants. Afr J Biotech. 2006;5(2):1142-45.

26. Deng Y, Yang G, Yue J, Qian B, Liu Z, Wang D, et al. Influences of ripening stages and extracting solvents on the polyphenolic compounds, antimicrobial and antioxidant activities of blueberry leaf extracts. Food Control. 2014;38:184-91

27. Auddy B, Ferreiro M, Blasina F, Lafon L, Arredondo F, Dajas F, et al. Screening of antioxidant activity of three Indian medicinal plants traditionally used for the management of neurodegenerative diseases. J Ethnopharm. 2003;84(2):131-8.

28. McLean EO. Soil pH and lime requirement. In Page, AL, Miller RH and DR. Keeney (eds.) Methods of soil analysis. Part 2 - Chemical and microbiological properties. (2 ${ }^{\text {nd }}$ Ed.), Agronomy,1982;9:199-223.

29. Piper CS. Soil and Plant Analysis. Hans Publishers. 1950;59(82):187-200.

30. Rhoades JD. Soluble Salts. In A. L. Page, R.H. Miller and D. R. Kenney (eds.) Methods of soil analysis part 2, chemical and microbiological properties. Agronomy Monograph. 1982;9:167-78.

31. Nelson DW and Sommers LE. Total carbon, organic carbon and organic matter. In: Methods of Soil Analysis, Part 2: Chemical and Microbiological Properties, second ed. 1982;561-93.

32. Peachey D, Roberts JL and Scot-Baker J. Rapid colorimetric determination of phosphorus in geochemical survey samples. J Geochem Explor. 1973;2(2):115-20.

33. Cappuyns V, Swennen R and De Nil K. Heavy metals and arsenic in alluvial sediments of the Grote Beek river: contribution of natural and antropogenic sources. Aardkundige Mededelingen. 2002;12:227-30.
34. Lindsay WL, Norvell WA. Development of DTPA soil test for zinc, iron, manganese and copper. Soil Sci Soc Am J. 1978;42(3):421-8.

35. Tessier A, Campbell PGC and Bisson M. Sequential extraction procedure for the speciation of particulate trace metals. Anal Chem. 1979;51(7):84450.

36. Karak T, Bhattacharyya P, Das T, Paul RK and Bezbaruah R. Non-segregated municipal solid waste in an open dumping ground: A potential contaminant in relation to environmental health. International Journal of Environmental Science and Technology. 2013;10(3):503-18.

37. Singh KP, Mohan D, Singh VK and Malik A. Studies on distribution and fractionation of heavy metals in Gomti river sediments-a tributary of the Ganges. India. J Hydrol. 2005;312(1):14-27.

38. Chai Y, Guo J, Chai S, Cai J, Xue L and Zhang Q. Source identification of eight heavy metals in grassland soils by multivariate analysis from the Baicheng-Songyuan area, Jilin Province, Northeast China. Chemosphere. 2015;134:67-75.

39. Alloway BJ. The origins of heavy metals in soils. In: Alloway, B. J. (Ed.), Heavy Metals in Soils. Chapman and Hall, London. 1995;38-57.

40. Juwarkar AA, Nair A, Dubey KV, Singh SK and Devotta S. Bio surfactant technology for remediation of cadmium and lead contaminated soils. Chemosphere. 2007;68(10):1996-02.

41. Rasmussen PE, Subramanian KS, Jessiman BJ. A multi-element profile of house dust in relation to exterior dust and soils in the city of Ottawa, Canada. Sci Tot Environ. 2001;267(1):125-40.

42. Tokalioglu $S$ and Kartal S. Multivariate analysis of the data and speciation of heavy metals in street dust samples from the organized industrial district in Kayseri Turkey. Atmos Environ. 2006;40(16):2797-05.

43. Acosta JA, Gabarrón M, Faz A, Martínez-Martínez S, Zornoza R and Arocena JM. Influence of population density on the concentration and speciation of metals in the soil and street dust from urban areas. Chemosphere. 2015;134:328-37.

44. Feng XD, Dang Z, Huang $\mathrm{WL}$ and Yang C. Chemical speciation of fine particle bound trace metals. Int J Environ Sci Tech. 2009;6(3):337-46.

45. Subramanian A, Kunisue $T$ and Tanabe $S$. Recent status of organ halogens, heavy metals and PAHs pollution in specific locations in India. Chemosphere. 2015;137:122-34

46. Pandey M, Pandey AK, Mishra A and Tripathi BD. Assessment of metal species in river Ganga sediment at Varanasi, India using sequential extraction procedure and SEM-EDS. Chemosphere. 2015;134:466-74.

47. Perin G, Craboledda L, Lucchese M, Cirillo R, Dotta L, Zanetta ML, et al. Heavy metal speciation in the sediments of northern Adriatic Sea - a new approach for environmental toxicity determination, in: T.D. Lakkas (Ed.), Heavy Metals in the Environment, vol. 2, CEP Consultants, Edinburgh,1985;454-56.

48. Zhao S, Feng C, Yang Y, Niu J and Shen Z. Risk assessment of sedimentary metals in the Yangtze Estuary: New evidence of the relationships between two typical index methods. J Hazard Mater. 2012;241:164-72.

49. Sundaray SK, Nayak BB, Lin S and Bhatta D. Geochemical speciation and risk assessment of heavy metals in the river estuarine sediments-A case study: Mahanadi basin, India. J Hazard Mater. 2011;186(2):1837-46.

50. Zhao FJ, McGrath SP, Merrington G. Estimates of ambient background concentrations of trace metals in soils for risk assessment. Environ Pollut. 2007;148(1):221-9.

51. Govindarajan M. Bioefficacy of Cassia fistula Linn. (Leguminosae) leaf extract against chikungunya vector, Aedes aegypti (Diptera: Culicidae). Eur Rev Med Pharmacol Sci. 2009;13(2):99-03.

52. Ezuruike UF, Prieto JM. The use of plants in the traditional management of diabetes in Nigeria: Pharmacological and toxicological considerations. J Ethnopharmacol. 2014;155(2):857-924.

53. Sowndhararajan K, Kang SC. Free radical scavenging activity from different extracts of leaves of Bauhinia vahlii Wight \& Arn. Saudi J Biol Sci. 2013;20(4):319-25.

54. Sharma KR, Agrawal M, Marshall MF. Heavy metals in vegetables collected from production and market sites of a tropical urban area of India. Food Chem Toxicol. 2009;47(3):583-91.

55. Street RA, Stirk WA, Van Staden J. South African traditional medicinal plant trade-Challenges in regulating quality, safety and efficacy. J Ethnopharmacol. 2008;119(3):705-10. 
56. Karak T and Bhagat RM. Trace elements in tea leaves, made tea and tea infusion: A review. Food Res Int. 2010;43(9):2234-52.

57. Devi KN and Sarma HN. PIXE-PIGE analysis of some Indian medicinal plants. Nucl. Instrum. Methods Phys Res Sect B. 2010;268(11-12):2144-47.

58. Gregor M. Metal availability, uptake, transport and accumulation in plants. In: Prasad, M.N.V. (Ed.), Heavy metal stress in plants-from biomolecules to ecosystems. Spinger-verlag, Berlin. 2004;1-27.

59. Kishore G, Ranjan S, Pandey A and Gupta S. Influence of altitudinal variation on the antioxidant potential of tartar buckwheat of western Himalaya. Food Sci Biotechnol. 2010;19(5):1355-63.

60. Sulaiman SF, Sajak AAB, Supriatno KLO, Seow EM. Effect of solvents in extracting polyphenols and antioxidants of selected raw vegetables. J Food Comps Anal. 2011;24(4):506-15.

61. Sang S, Lapsley K, Jeong WS, Lachance PA, Ho CT and Rosen RTJ. Antioxidative phenolic compounds isolated from almond skins (Prunus amygdalus Batsch). J Agric Food Chem. 2002;50:2459-63.

62. Villano D, Fernandez-Pachon MS, Troncoso AM, Garcia-Parrilla MC. Comparison of antioxidant activity of wine phenolic compounds and metabolitos in vitro. Anal Chim Acta. 2005;538(1):391-8.
63. Fresco P, Borges F, Diniz C, Marques MPM. New insights on the anticancer properties of dietary polyphenols. Med Res Rev. 2006;26(6):747-66.

64. Kohri S, Fujii H, Oowada S, Endoh N, Sueishi Y, Kusakabe M, et al. Anoxygen radical absorbance capacity-like assay that directly quantifies the antioxidant's scavenging capacity against AAPH-derived free radicals. Anal Biochem. 2009;386(2):167-71.

65. Bentayeb K, Vera P, Rubio $C$ and Nerín $C$. The additive properties of oxygen radical absorbance capacity (ORAC) assay: The case of essential oils. Food Chem. 2014;148:204-08.

66. Złotek U, Mikulska S, Nagajek M, Swieca M. The effect of different solvents and number of extraction steps on the polyphenols content and antioxidant capacity of basil leaves (Ocimum basilicum L.) extracts. Saudi J. Biol. Sci In Press, Accepted Manuscript, Available online 6 August 2015.

67. Fu R, Zhang Y, Guo $Y$ and Chen F. Antioxidant and tyrosinase inhibition activities of the ethanol-insoluble fraction of water extract of Sapium sebiferum (L) Roxb. leaves. S Afr J Bot. 2014;93:98-104.

68. Huang W, Shen S, Nimalaratne C, Li S, Majumder K and Wu J. Effects of addition of egg ovotransferrin-derived peptides on the oxygen radical absorbance capacity of different teas. Food Chem. 2012;135(3):1600-7.

\section{SUMMARY}

- Highest antioxidant activity was found in methanoilc extract of leaf.

- Total phenols content were highest in methanolic extract of leaf.

- Maharashtra sample showed significant higher antioxidant activity.

- Marginal variation in $\mathrm{Fe}, \mathrm{Cu}$ and $\mathrm{Zn}$ content in both leaf samples.

- Positive significant correlation with elements, phenolic content and antioxidant studies in methanolic extracts.

- Non essential heavy metals were absent in both the $C$. fistula samples. 